\title{
DON QUIJOTE SONADO POR LAS CASAS \\ (EN DOS INÉDITOS DE M. A. ASTURIAS)
}

La obra teatral del Nobel guatemalteco Miguel Ángel Asturias (1899-1974) incluye una pieza de argumento lascasiano, La Audiencia de los confines. Publicada por primera vez en 1957 y después incluida en la edición del Teatro de 1964, dicha pieza, que el propio autor define "crónica en tres andanzas», recupera argumentos e informaciones procedentes de varias fuentes del siglo XVI sobre el Obispo de Chiapas (el exordium, p.e., juega muy explícitamente con la famosa Carta al Emperador de fray Toribio de Benavente "Motolinía») y los refunde dentro de un esquema dramático que, alternando personajes históricos e imaginarios, escenas de ambiente español e indígena, desenvuelve la trayectoria de su acción a través de un sistema de doble escena (mitad de escenario la ocupa un adoratorio de ídolos Mayas y la otra el despacho del Gobernador).

En la última etapa de su vida, y concretamente en 1972, Asturias modificó notablemente dicha pieza, aprovechando la ocasión de una puesta en escena y los consejos teatrales de la compañía. Trabajando directa y materialmente sobre una copia de la edición Losada (facsímil núm. 1), Asturias insertó el contrapunteo de unos coros en verso e introdujo muchas variantes, pequeñas y grandes.

Aunque la obra se haya representado, en la nueva versión, con el título de Las Casas, el Obispo de Dios, el texto de dicha versión sigue inédito ${ }^{1}$, con la sola excepción de los coros, que se publicaron aisladamente después de la muerte de Asturias (9 de junio de

1 Tanto la copia de la edición Losada anotada por Asturias como los dos dss. que recogen y sacan en limpio sus interventos forman parte del fondo Asturias de la Biblioteca Nacional de París. 
1974 en Madrid), tanto en distintos periódicos como en la plaqueta conmemorativa en que se reunieron los textos del homenaje que la Biblioteca Nacional de París rindió, el 9 de julio de 1974, a la memoria del gran escritor guatemalteco, que, en su legado testamentario, había confiado a la institución francesa la salvaguarda y conservación de todos sus papeles ${ }^{2}$.

Entre las variantes más significativas de la nueva versión, que pronto se publicará, con ocasión del centenario asturiano y en el marco de la Colección Archivos, cabe una de interés cervantino, la cual es el punto de arranque de la presente ponencia.

La andanza tercera se abre con una fantasía onírica en que un Las Casa setentón «Sueña que está en presencia del emperador Carlos V, en la controversia teológico-política que sostuvo en Valladolid con el doctor Juan Ginés Sepúlveda». En La Audiencia de los confines el sueño del protagonista se concluía con su arrepentimiento por haber tenido esclavos y por haber aconsejado la trata de negros.

En la versión refundida asistimos en cambio a una aparición onírica de Don Quijote y Sancho. Dicha aparición resulta mucho más fuente que la de Carlos $\mathrm{V}$, tanto desde un punto de vista teatral, puesto que los héroes cervantinos hablan, mientras que el César era un interlocutor mudo, como desde un punto de vista histórico, por ser la aparición del hidalgo profética y anacrónica con respecto a la cronología de la pieza y por presentarnos al héroe cervantino y a su escudero como dobles evidentes, y por lo tanto como modelos de interpretación para el diálogo entre el dominico y Comacho, su lacayo negro, que concluye la escena. He aquí el texto del inserto cervantino (que en un primerísimo borrador, ms., aparecía bajo el título de «Evocación de Don Quijote», cfr. facsímil núm. 2):

SANCHO PANZa (A Don Quijote que aparece): Debes descansar, mi amo... СомAcho (Viene por el fondo): Debe descansá, amito... debe descansá... DON QUIJOTE: Para un caballero errante, el descanso es el combate contra los molinos de viento. Yo, Caballero de la Triste Figura, iré más allá del Océano, más allá de los mares tenebrosos, para librar combate contra la injusticia. Pediré a mi Rey pasar a las Indias y tú, Sancho, mi caballo y yo, esperaremos en Sevilla, la nave que nos conducirá...

Fray BARTOlomé (A Don Quijote): ¡No, tú no!, yo ya estoy aquí. Mi lucha es imagen de la tuya. Mucho antes que Cervantes te insuflara vida inmortal, yo viví en mi propia carne todos los sufrimientos que se clavaron en la tuya...

2 La traducción francesa de JULIÁN GARAvito, leída en la ceremonia del 9 de julio de 1974, aparece en las actas de la sesión (Hommage à Miguel Ángel Asturias. París, Bibliothèque Nationale, 1974); otra traducción, siempre al francés, de Gabrielle Chiarini, se publicó en Nouvelles de Méxique, núm. 78-79, juilletdécembre de 1974. El texto en castellano, en cambio, apareció en México, en Diorama, suplemento literario de Excelsior, el día 8 de septiembre de 1974. 
$\mathrm{Al}$ insertar este episodio, Asturias nos sugiere un juego de tópicos muy fino, estableciendo una comparación y un diálogo entre dos estampillas y dos fortunas: la del héroe cervantino y la del Obispo de Chiapas.

A lo largo de los siglos, la fama del Caballero de la Triste Figura y la del Defensor de los Indios se han vinculado, tal vez un poco anacrónicamente, a las retóricas, complementares y complementarias, de la utopía y de la justicia.

Asturias, mediante la evocación consciente de estos horizontes interpretativos, esboza una reflexión que desde el paralelo explícito entre las dos parejas de personajes (Sancho : Don Quijote = Comacho : Las Casas) nos sugiere otro paralelo, entre los respectivos autores. En este sentido la aparición onírica de Don Quijote supone, aunque entre líneas, la de Cervantes y, por lo tanto, la asunción de una máscara cervantina por parte del propio Asturias.

La idea de que Don Quijote pida permiso para pasar a Indias («Yo, Caballero de la Triste Figura, iré más allá del Océano, más allá de los mares tenebrosos, para librar combate contra la injusticia. Pediré a mi Rey pasar a las Indias y tú, Sancho, mi caballo y yo, esperaremos en Sevilla, la nave que nos conducirá») evoca sin falta, también en la memoria del exegeta más torpe y distraído, el recuerdo del análogo permiso solicitado por Cervantes. Evidentemente, lo que Asturias quiere es que su lector, acostumbrado ya al continuo juego de fuentes que el texto propone desde la andanza primera, identifique el héroe cervantino como alter ego posible de su autor.

La réplica de fray Bartolomé («iNo, tú no!, yo ya estoy aquí. Mi lucha es imagen de la tuya. Mucho antes que Cervantes te insuflara vida inmortal, yo viví en mi propia carne todos los sufrimientos que se clavaron en la tuya»), no sólo completa el itinerario, evocando directamente el nombre de Cervantes, sino que añade otra hipótesis de identificación: Don Quijote, además de alter ego literario de Cervantes, sería alter ego español de Las Casas. El anillo que falta, la equis que completa la proporción, es evidentemente el nombre del propio Asturias, autor y alter ego de Las Casas como Cervantes lo es de Don Quijote.

Este declarado cervantismo lascasiano de Asturias es documentado también por el texto de su última intervención pública (Asturias murió en Madrid el 9 de junio de 1974, regresando de Sevilla, donde unos días antes había leído su texto en el Congreso del V centenario lascasiano).

En el texto de esta última intervención suya, Asturias dibuja un autorretrato heterodoxo que, por ser al mismo tiempo cervantino y lascasiano, subraya y hasta reivindica para el escritor más ameri- 
cano de América (el del realismo mágico, las Leyendas, la oralidad indígena, etc.) un abolengo doblemente hispánico.

Claro está, evocar a Cervantes en Sevilla con ocasión del centenario lascasiano, siendo Premio Nobel de Literatura y embajador en la UNESCO, algo puede tener de juego retórico, pero detrás del juego nos deja entrever las profundas raíces hispanas de un arte literario cuyas muchas deudas, para con la literatura medieval, el teatro clásico, las crónicas de la conquista, el erasmismo y la ejemplaridad del Siglo de Oro, serían obvias y evidentes, de no haber sido tanto subestimadas en y por la difusión de la desordenada avalancha de tópicos americanistas e indigenistas que, en coincidencia con el Nobel y la contestación del '68, vertebraron ideológicamente la imagen pública del autor.

En Asturias hay, por supuesto, una fuerte afirmación política y cultural, de americanismo e indianismo, es decir, mucho Las Casas, pero también hay mucha vanguardia y mucho hispanismo, es decir, mucho Cervantes. Su obra no se puede bien valorar si no se comprende este juego, totalmente hispánico, de perspectivas y lejanías, esta capacidad de redescubrir, reinventar y reinventariar América desde Europa, viendo a los indios por fuera y desde fuera, mirando hacia Las Casas desde Cervantes.

En este sentido, no cabe la menor duda de que la ponencia sevillana pronunciada por Asturias en vísperas de su muerte, en el junio del año 1974, complete el proceso de reajuste ideológico y literario empezado dos años antes con la refundición de La Audiencia de los confines en Las Casas: el Obispo de Dios.

Por si fuera poco, el texto de dicha ponencia tiene muchísimos puntos de contacto con un breve inédito (cinco hojas), titulado Prólogo, conservado entre los papeles del Fondo Asturias relacionados con Las Casas: el Obispo de Dios y al parecer elaborado por Asturias con fin de publicarlo como prefacio de la pieza refundida. Los dos textos, el de la ponencia y el del prólogo, guardan una relación tan evidente y fuerte que cada uno de ellos bien puede considerarse una versión con variantes del otro. La hipótesis de prologar en 1974 la última versión de una obra teatral escrita en 1957 y reelaborada en 1972 (modificando una copia de la edición Losada de 1964) no llegó a concretarse del todo. Al aceptar la invitación para el Congreso sevillano, Asturias quiso dar a su profesión de hispanismo otra destinación y otra tribuna; lo confirmaría también el hecho de que Las Casas: el Obispo de Dios aparezca sin prólogo en el taquigrafiado en limpio que se encargó con fin de incluir el texto en el volumen misceláneo que Asturias estaba preparando y que no llegó a publicarse, por causa de su repentina muerte. 
De todas formas, el texto de Prólogo contiene, en su trabajado exordium y en su final, las más fuertes enunciaciones del hispanismo de Asturias, un hispanismo tanto lingüístico y cultural como sorprendentemente no exento de acentos retóricos rotundamente sagrados y hasta estruendosamente patrióticos (hay que considerar que todavía estamos en las postrimerías de la España franquista):

\begin{abstract}
por la señal de la santa luz de España, inicio este prólogo con todos los signos del zodíaco en las yemas de los dedos. El menos español y el más español. El menos español por mi ancestro indígena y el más español por mi lengua. El menos español por mi lascasismo y el más español por mi quijotismo. Un prólogo me manda la andante caballería de los relojes que señalan los minutos de las eclipses totales (inserto ms., después tachado, que dice: «-España ha sufrido tanto—», cfr. facsímil, núm. 3).
\end{abstract}

En los siguientes párrafos Asturias complementa su elogio de España con un elogio del tránsito y de la andanza española (España como patria del tránsito), evocando la Reconquista y Toledo y Andalucía, convocando a su festín de palabras al Cid, al Greco, a Goya y hasta a los Conquistadores de América, víctimas de la leyenda negra lascasiana. Por un lado la retórica del tránsito se refleja en la idea que "día a día comienza el paraíso», por otro en la metáfora, brillante y quijotil, de España como libro, como espacio que se puede leer, como espejo de «la pluralidad maravillosa de España» y de «lo singular de sus regiones», enumeradas por Asturias con empecinada y casi unamuniana "devoción de hijo», desde las más antiguas y cristianas hasta «las Canarias afortunadas, que ya huelen a América». Tanta y tan quijotesca enumeración de nombres y lugares desemboca en sanchismo, elogio de lo cotidiano y del pueblo hacedor:

Imágenes y palabras que se anudan y se desnudan, decorados que representan a la España visible, exterior, colorida, escenario que barren tolvaneras de la historia, césares, reyes de baraja, razas, culturas, religiones, cides, quijotes, santos, poetas (...) pero hay algo que hojeando este hermoso libro nos seduce más, mucho más: el pensar que en estas ciudades, que [en] estos campos hubo, hay y habrá lugar siempre para la pasión encadenada, latente del hombre común, del que hace existir todas las cosas.

Bajo la deslumbrante superficie de España, Asturias nos exhorta a perseguir y encontrar las raíces históricas de unos imperios en la profundidad metahistórica de un pueblo:

Pero no nos contentemos con la contemplación de estas imágenes, su plasticidad, sus colores, su gracia tipográfica, vayamos a lo hondo, asociemos ideas que no nos dejen caer en la tentación de los tópicos, ideas 
que nos permitan valorar lo cotidiano, lo verdadero, lo cierto, pensando en una España - ¿otra?-, no, la misma, porque la misma ha sido y será siempre, señora de pueblos, por tener un pueblo señor.

¿A qué tanta exaltación? ¿Nostalgia de apólide? ¿Simple e intrascendente sobredosis de retórica? ¿Nacionalismo espiritual? ¿Viejazo? Asturias se nos explica en una última página que, en comparación con las trabajadísimas hojas anteriores, casi parece una copia en limpio (facsímil núm. 4). La nota es tan melancólica que casi nos permite imaginarnos adivinos por saber que ese hombre se iba a morir a los pocos días:

\begin{abstract}
La patria material se me fue muriendo dentro, y de ella fue quedando otra patria. La patria espiritual. La mía. La honda. Honda como un estanque de agua (...) Verme en ese estanque, no era simplemente contemplar mi imagen en un espejo líquido. No. Era verme en sus mares, en sus lagos, en sus ríos, en sus fuentes, en sus nubes, en sus cielos (...) Materialmente, Patria, me asomaba a tu yo íntimo, a tu esperanzada transparencia de fuegos de plata (...) a tu misterioso callar, con el grito del corazón en los labios, con la palpitación de castañuelas de alegría, en los dedos, con todo lo que signifique orquesta, fiesta, esplendor de regocijos... Patria...
\end{abstract}

Festival de tópicos, pero en serio. Muy en serio. Demasiado en serio para que nos permitamos aquí el fácil lujo de la ironía menor. Hace falta aquí la ironía grande, amarga y espantosa, de Cervantes y de la Historia. La que rodea la muerte cuerda de Alonso Quijano, el Bueno, vuelto a su precaria identidad de hidalgo provinciano, piadosa y castiza, después de haber conocido la visionaria locura de la caballería andante y de la Triste Figura. La que también se encuentra en la cláusula testamentaria con la cual fray Bartolomé de Las Casas «manda que se recojan todos los libros y cartas tocantes a los indios (...) porque si Dios determinare destruir a España, se vea que es por las destrucciones que hemos hecho en las Indias y parezca la razón de su justicia». La ironía grande, en suma, de dos muertes vertebrales y paradigmáticas, conformes y sosegadas, cristianas y hasta piadosas, pero también llenas de intención y cargadas de inmanente lucidez.

Del mismo modo, Asturias, el Girador, el Gran Lengua, el reflejarse retóricamente en el estanque y en los paisajes de España, parece buscar en las hojas de su prólogo el consuelo de una verdad sancha, manchega y menor, persiguiéndola hasta encontrar la recogida dignidad de una muerte española y quijana.

El suspirado «Patria» que cierra su prólogo, además de dialogar con las muertes de Alonso Quijano y de Bartolomé de Las Casas, es en este sentido sinónimo perfecto de ese famoso "otra vida» que, desde las primeras páginas de Los trabajos de Persiles y Sigismunda, 
cierra otro prólogo y sella otra muerte. Allí también, al igual que en el borrador de Asturias, hay un autor decepcionado, íntimamente convencido de su propio valor poético y teatral, muy a pesar de que sus contemporáneos le hayan condenado, y con razón, a una fama de novelista. Allí también un hombre viejo y cansado habla con sus lectores de muerte y de regocijo, mientras sus fuerzas se van acabando. Allí también hay una tentativa de reanudar el roto hilo que nos une a esa patria, común y perdida, que llamamos literatura: «La patria material se me fue muriendo dentro, y de ella fue quedando otra patria. La patria espiritual. La mía. La honda».

Una patria tan honda y personal que, al refundir su pieza en 1972, el autor había querido retratarla entre líneas, matizando el contrapunteo entre las dos patrias paralelas del Adoratorio y el Despacho, restituyendo la palabra tanto a los indios como a los soldados españoles (a través de la forma, a la vez clásica y romántica, del coro trágico) y, sobre todo, desdibujando, a través de las anónimas voces de los dos pueblos, ese perfil esquemático y un poco maniqueo que, al escribir la pieza, en la Argentina de 1957, le había permitido cifrar en metáfora su discurso y dolor de exiliado político, recién expatriado de Guatemala.

El inserto cervantino, con su juego de voces, que tanto se parece al de otros importantes inéditos asturianos posteriores al Nobel (sobre todo los títeres de Amores sin cabeza), es a la vez ejemplo y método de esta matización y de este pasaje de la metáfora política a la metáfora universal: por un lado, participa directamente del reajuste ideológico de la pieza lascasiana y por otro se nos ofrece como una de las más explícitas muestras del paradójico hispanismo cultivado por Asturias en la ultimísima etapa de su vida. En muchos textos de esta etapa (éditos e inéditos) la revalorización de la herencia identitaria española es tanto más explícita y progresiva cuanto más se traduce al acto bajo la forma, muy teatral, de un diálogo entre máscaras complementarias, que, en nuestro caso específico, coinciden con la imagen, metaliteraria y transhistórica, de dos héroes de la cultura cuya fortuna, identidad e hispanidad se han concretado en hacerse Fiscales y espejos de la España imperial y de sus contradicciones.

No cabe la menor duda de que le evocación teatral, la ponencia sevillana y su variante prológica, además de compartir el mismo tono retórico, dibujan el perfil de un Quijote americano a la vez tópico y crítico.

Héroe de la patria del tránsito, ejemplo y máscara de una identidad plural, este Quijote es el eje, posible por paradójico, de un tradicionalismo y de un patriotismo cultural de corte casi unamuniano. Una alucinación trágica y senil, teatral y centrada en la 
conciencia (cristiana) de la agonía, en el sueño (quijotesco) de la libertad y, sobre todo, en una muy original reivindicación del valor (lingüístico) y de los valores (lascasianos) que, en la visionaria prosa del último Asturias, escenifican la polifacética esencia espiritual de la presencia española en América.

MARCo CIPOLlONI

Università di Brescia 